\title{
Nepotism as a Negative Factor in Organization Performance
}

\author{
Alma Shehu Lokaj \\ University Haxhi Zeka, Peja/Kosovo \\ alma.shehu@unhz.eu
}

\section{Doi:10.5901/ajis.2015.v4n2s1p9}

\section{Abstract}

Nepotism in the work place has its pro and contra. In this paper nepotism it will be seen as a negative factor in the organization performance, although there are different opinions that nepotism not always has a negative impact for the organization performance. To prove this a research has been done in some companies from Dukagjini Region. Nepotism in itself is not considered a bad think if the companies hire qualified people but the research shows that nepotism in Kosovo companies is a negative factor and as such it negatively influence in the performance of the employees and of the organization. In Kosovo it seems that is not enough and necessary to have a degree and to be super qualified for the job you apply for but is indispensable to know an influential person who will help to find a job. The problem starts with a non transparent recruiting system and you will see yourself led by an unqualified and irresponsible person.

Keywords: nepotism, performance, negative factor, companies, employment

\section{Introduction}

According to Wikipedia the term comes from Italian word nepotismo, which is based on Latin root nepos meaning nephew. Since the Middle Ages and until the late 17th century, some Catholic popes and bishops, who had taken vows of chastity, and therefore usually had no legitimate offspring of their own, gave their nephews such positions of preference as were often accorded by fathers to son. The Business Dictionary define nepotism as a Practice of appointing relatives and friends in one's organization to positions for which outsiders might be better qualified. Nepotism is considered a problematic phenomenon in our country and almost all public and in some cases also in private organizations if you are not a member of a certain party, if you don't know influenced persons and if you are not a relative with the employer you will not have a job in most cases. According to a study done by the Institute of Criminology and Criminal Justice Kosovo nepotism often is called the modern day corruption and in most states, the legal sanctions for this phenomenon fall under the law against corruption in the Penal code. According to the research of the ICCJ in Kosovo in the question: Do you believe that political beliefs play a role in finding employment we see that the political beliefs play an important role in finding a job in Kosovo and this is a concern issue in our country.

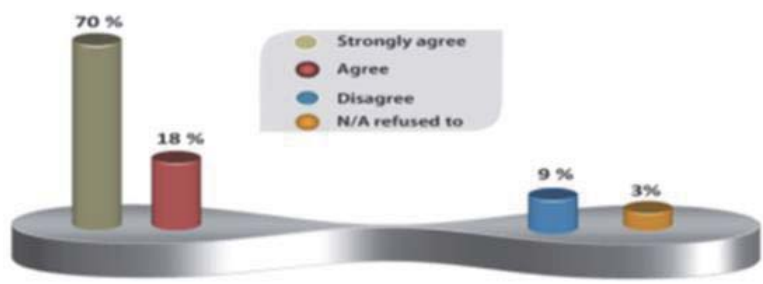

Source: Public opinion survey of ICCJ in Kosovo

The U.S. law does not prohibit the hiring of a relative; however studies show that anywhere from $10-40 \%$ of U.S. companies try to maintain formal policies seeking to sustain formal practices that prohibit such an act. While, in Italy according to an article published in BBC the Supreme Court in Italy has actually decided that nepotism is illegal. They even sentenced the offenders in the case to 14-21 months in prison. 


\section{Literature Review}

Özler asserts in his paper "When a person appointed/promoted on the basis of family regardless of ability, education, skills etc. it's called nepotism" (as cited in Sadozai, Zaman, Marri and Ramay, 2012).

In his paper "Cronyism and Nepotism are Bad for Everyone: The Research Evidence" Pearce said that "decades of research in political science, economics and anthropology have demonstrated that nepotism and cronyism are bad for organizational performance. The work of my colleagues and I has documented how dysfunctional they are for employees and their supervisors. Nepotism and cronyism damage exactly the kinds of social relationships that make for a humane and tolerable workplace and foster organizational performance".

According to Arasly $\mathrm{H}$. at al. (2006) nepotism is an unprofessional phenomenon that provides benefits merely to the family members. Therefore nepotism paralyzes human resources practices and affects the level of satisfaction among employees.

According to Suba Lakshminarasimhan (2011) unfortunately, not all family members and relatives come with the right merit to be employed for a particular position or a role. When the manager is not allowed to control a subordinate just because she is a relative of an employer, imagine what will happen to the company's discipline. Nepotism allows rules to be broken and can lead to a chaotic situation for business owners.

Farahmand (2013) in his work says that nepotism affects the quality of human resource in an organization as candidates are hired due to their affiliations family ties rather than their requisite skill. A situation may arise in which the potential recruits do not well suit the job specification like the other candidates are appropriately qualified.

\section{Nepotism in Kosovo Organizations}

The research has been done in five organizations in Dukagjini area. The total number of the respondents is 50 in all the organizations. Below are reflected the opinions of the employees regarding the nepotism issues.

Question_1. Elsewhere in your organization, are relatives of employees employed?

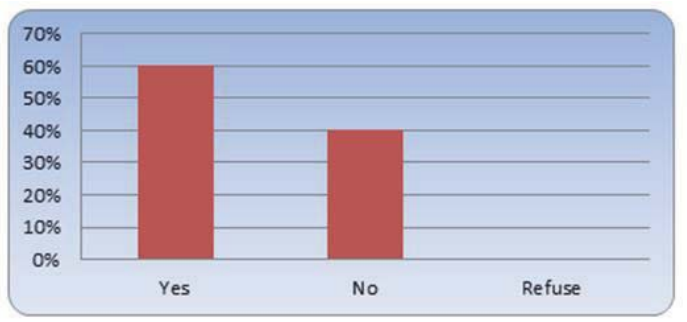

To this question $60 \%$ of the employees declare that there are relatives of employees employed in the organization. $40 \%$ of them declare that they are not relatives.

Question_2. In your opinion, does nepotism impacts the morale of the workplace?

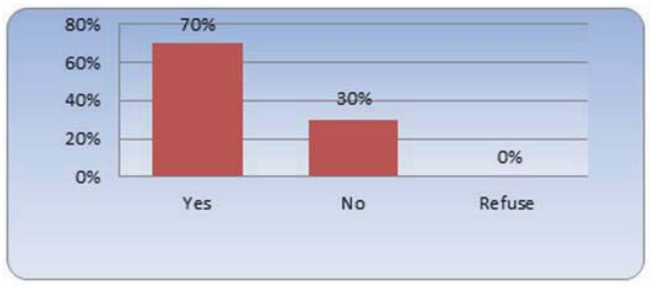

A high percentage of the respondents (70\% of them) think that nepotism impacts the morale of the workforce. $30 \%$ of them did not agree that nepotism impacts the morale of the workforce. The employees are concerned about this fact and 
of course this will affect their performance in their workplace.

Question_3. Do you think that the policies are made but are not applied to fight nepotism?

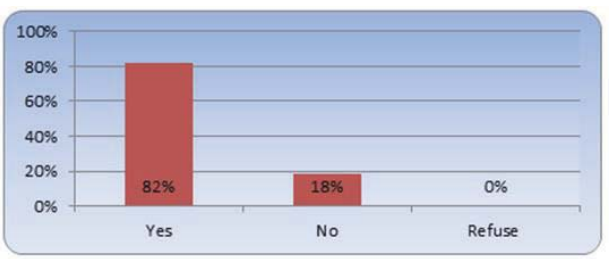

To this question $82 \%$ of the respondents declare that there are policies against nepotism but this in never applied in their organization. $18 \%$ of the respondents think that the policies exist and are applied in their organization.

Question_4. Do you think that in organizations which work two or more familiars are less effective than the organizations that prohibit it?

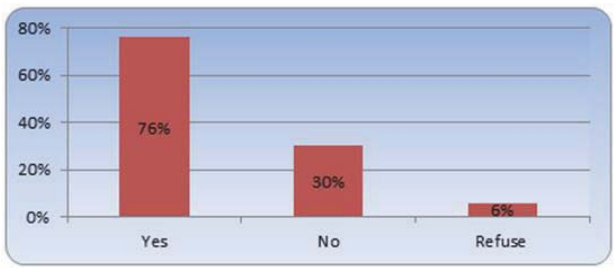

To this question $76 \%$ of the respondents think that the organizations with two or more familiars are less effective than the organizations that prohibit nepotism. $30 \%$ of the respondents think that the organizations are not less effective even if there are two or more familiars within the organization.

Question_5. Do you think that nepotism complicates personnel's role in training?

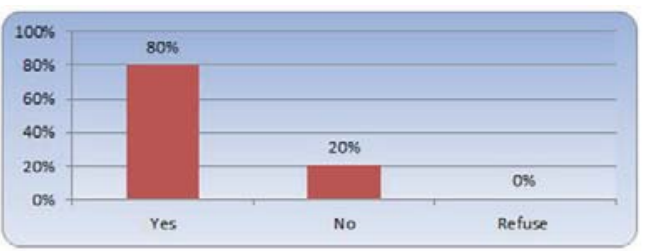

In this question $76 \%$ of the respondents agree that nepotism complicates personnel's role in training and $24 \%$ think that nepotism doesn't complicates this role.

Question_6. Do you think that family dominated organizations are more concerned with taking care of their family than the business?

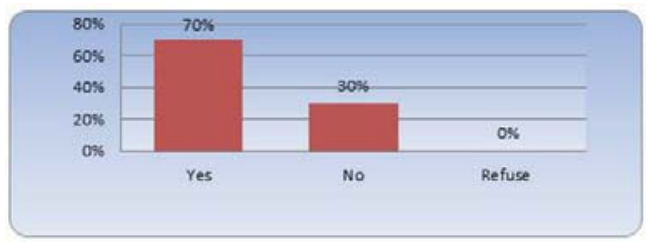


To their experience in the workplace $70 \%$ of the respondents think that family dominated organizations are more concerned with taking care of their familiars than the business and 30\% say that this is not true.

Question_7. Do you think that executive's relatives are frustrated by never really knowing whether they succeed on their talent or family ties?

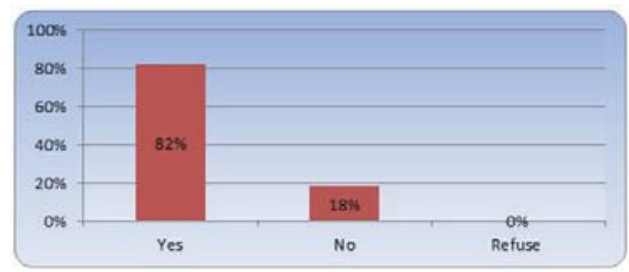

To this question $82 \%$ of the respondents think that executives' relatives are frustrated by never knowing whether they succeed on their talent or family ties and the other $18 \%$ think that they know if their succeed on their talent of family ties.

Question_8. Do you think that organizations can obtain better managerial talent by recruiting relatives?

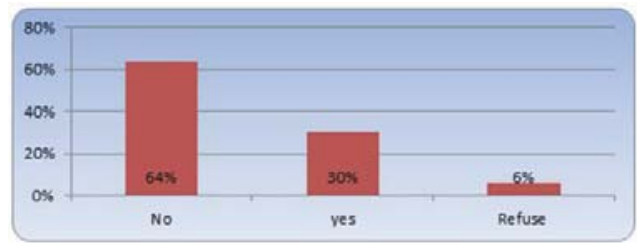

To this question $64 \%$ of the respondents declare that if the organization recruit relatives than will not have a better managerial talents and $30 \%$ declare that by recruiting relatives the organization will obtain better managerial talent.

Question_9. Do you think that nepotism is a form of corruption?

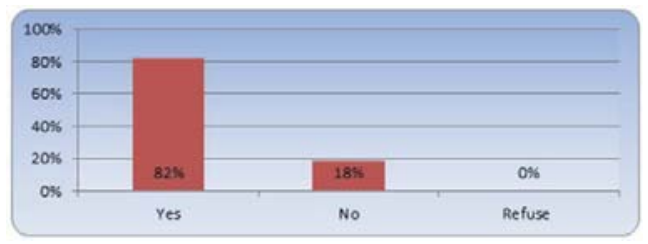

I high percentage ( $82 \%$ of them) thinks convincingly that nepotism is a form of corruption and $18 \%$ of them think that nepotism is not a form of corruption.

Question_10. Would you be in support of policy that limited nepotism?

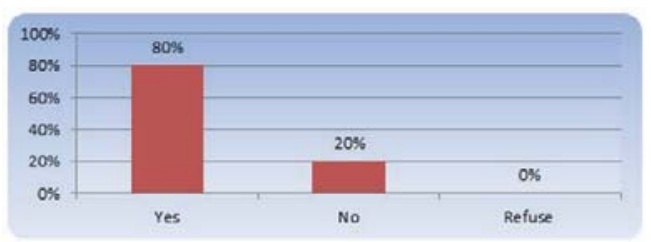

To the last question $80 \%$ of the respondents will support the policy that limited nepotism and $20 \%$ of them will not. 


\section{Conclusion}

As we see from the literature review and the research on the nepotism in the organizations in Kosovo we can conclude that nepotism is a form of discrimination on which members of the family or friends are hired not because of their talents, experience but only because they are relatives to the owner or to the executives of the enterprise. Nepotism is a common problem in almost all the organizations and it affects the morale, the culture and overall the performance of the organization. Nepotism is considered a form of corruption and actions must be taken to combat this phenomenon even the public say that is impossible to combat the nepotism. The organizations in Kosovo, especially in Dukagjini region where the research has been done must take into consideration the fact that by hiring employees based in family ties their organization will never had the performance and the success they want to achieve.

\section{References}

Jone., Pearce., Cronyism and Nepotism are Bad for Everyone: The Research Evidence The Paul Merage School of Business

Arasly, H., Bavik, A., \& Ekiz, E. (2006). The effects of nepotism on human resources management. The case of three, four and five stars hotels in Northern Cyprus. International Journal of Sociology and Social Policies, 26(7/8), 295-308. doi:10.110810144333 0610680399

Lakshminarasimhan, S. (2011). Nepotism: Is it a Boon or Bane for the Organization? Retrieved June 10, 2015, from http://www. brighthub.com/office/human-resources/articles/119324.aspx

Farahmand, Negar.,(2013). Impact of nepotism on turnover intention and service recovery performance: the case of private hospital in TRNC

http://www.businessdictionary.com/definition/nepotism.htm/\#ixzz3aZTJVxxEC 